\title{
VALIDITY OF ASCORBIC ACID AS VIRAL INACTIVANT FOR INFECTIOUS BOVINE RHINOTRACHEITIS VIRUS AND BOVINE VIRAL DIARRHEA VIRUS
}

\author{
ABD EL FADIL, MAHA RAAFAT, RASHA I. EL HAWARY and \\ EFFAT L. EL-SAYED
}

Veterinary Serum and Vaccine Research Institute, Abbassia, Cairo, Egypt

(Manuscript received 11 July 2017)

\begin{abstract}
$\mathrm{T}$ he present study was devoted to assess the potentiality of ascorbic acid (vit.C) catalytic with copper sulphate as inactivator for Infectious Bovine Rhinotracheitis Virus (IBRV) and Bovine Viral Diarrhea Virus (BVDV) compared with the conventional inactivants Binary Ethylene Imine (BEI). Stock viruses suspension of the two viruses were prepared. Virus infectivity titer were $10^{7.5}$ and $10^{6.5}$ respectively. The (BVD) and (IBR) viruses for suspension were inactivated separately with different concentrations $(0.5,1.0$ and $1.5 \mathrm{mg} / \mathrm{ml})$ of ascorbic acid. The treated viruses were incubated at $37^{\circ} \mathrm{C}$ incubator with continuous stirring for different period of time. It was found that the ascorbic acid induced complete virus inactivation at concentration of (1.0 and $1.5 \mathrm{mg} / \mathrm{ml}$ ) after (24 and 18) hrs for BVDV and after (more than $24,24 \mathrm{hrs}$ ) for IBRV. While $0.001 \mathrm{M}$-BEI induced complete virus inactivation within 4 and 6 hours post treatment at $37^{\circ} \mathrm{C}$ respectively. Safety tests were carried out for the inactivated viruses either by using ascorbic acid or BEI, both of them was proved safe when inoculated MDBK tissue culture, in mice and in rabbit revealing complete virus inactivation. This study concluded that the optimum ascorbic acid concentration for IBRV and BVDV is $(1.5 \mathrm{mg} / \mathrm{ml})$ because it made complete viral inactivation for two virus with 24 hour for each virus. Further study should be focused on IBRV and BVDV ascorbic acid inactivated vaccine to envisage the animal immune response comparing with traditional method (BEI inactivated vaccine) with the presence of ascorbic acid as an immune modulator agent in its composition especially in its nano form.
\end{abstract}

\section{INTRODUCTION}

Bovine Viral Diarrhea Virus belongs to family Flaviviridae, genus pestivirus genome ORF single-stranded, positive sense RNA virus (Ridpath,2005), Infectious Bovine Rhinotrcheititis belongs to family Herpesviridae, genus alpha herpesvirus its genome is double stranded DNAvirus (Brian et al.,2010). The two previous viruses are economically important viral pathogen of cattlecausing BRDV syndrome. Combined Binary inactivated vaccines containing the two viruses are used extensively as an aid in prevention of Bovine respiratory syndrome(BRD) using BEI as an inactivant. Inactivation of these previous viruses is essential for the preparation of vaccines, diagnostic reagents and research purposes. Currently recommended inactivating 
agent for this virus is a very expensive Binary Ethylenimine (BEI) chemical and potentially carcinogenic (Girard et al., 1977), other chemicals like formaldehyde and phenol not only inactivate the virus but also adversely affect its antigenicity. There is therefore a need to find alternative inactivating agents which are not expensive and are easily available and doesnot effect in antigencity and immunogenicity. It was demonstrated by (Turner, 1964). That ascorbic acid undergoing auto oxidation catalyzed by cupric ions inactivated vaccinia virus (White et al., 1986). Subsequently this was confirmed with other DNAand RNA viruses and it was also shown that the inactivated viruses retained good antigenicity (Rawal et al., 1995). Recent studies have shown that this agent could also inactivate HIV7 and bacteriophages (Murata et al., 1986) and interest has been renewed for using this chemical as an antiviral agent. Keeping this in mind the effect of ascorbic acid on the viruses was investigated and the study here indicate that this chemical along with cupric ions is capable of causing complete and irreversible inactivation of (IBRV) and (BVDV) without adversely affecting the antigencity.

\section{MATERIALS AND METHODS}

\section{Viruses and Cell Culture:}

Bovine Viral Diarrhea virus (BVD), Egyptian cytopathic strain (Iman strain) of a titer $10^{5.5} \mathrm{TCID}_{50} / \mathrm{ml}$ and Infectious Bovine Rhinotracheitis (IBR) virus, a local Abou Hammad strain of a titer $10^{7.5} \mathrm{TCID}_{50} / \mathrm{ml}$.

The two viruses were obtained from RinderPest like Diseases department, Vet. Serum and Vaccine Research Institute, Abbasia, Cairo, Egypt (VSVRI), and propagated and titrated on Madin Darby Bovine Kidney (MDBK) cell line cultures. The MDBK cells were grown and maintained in minimum essential medium with Earle's salts (MEME) supplemented with $1 \%$ antibiotic-anti mycotic $100 x$ solution and $10 \%$ new borne calf serum (NCS). Both MDBK cells and NCS were proved to be free from Mycoplasma and adventitious BVDV strain.

\section{Chemicals:}

\section{Ascorbic Acid and Copper Sulphate:}

These salts were supplied by Sigma Chemical Company (USA). Fresh Stock solutions containing $0.01 \mathrm{M}$ of copper sulphate and $0.5 \mathrm{M}$ of ascorbic acid were prepared and sterilized by membrane filtration.

\section{Binary Ethylenimine (BEI):}

(2 Bromo Ethylamine Hydrobromide 95\% d.w. $204.90 \mathrm{HV}$ ) was supplied by Aldrich chemical Co. Ltd. Grillingham Dorest. England. It was prepared according to Girard et al., (1977).

\section{Sodium Thiosulphate Solution:}

It was used at a final concentration of $2 \%$ to stop the reaction of the (BEI) inactivate. 


\section{Inactivation experiment:}

1- Using Binary Ethylene Amine:

BEI was added to the both (BVD\&IBR) viral suspension with a final concentration 0.01 of $0.01 \mathrm{M}$. The treated viruses were incubated at $37^{\circ} \mathrm{C}$ with continuous stirring. The inactivation process was stopped by addition of sodium thiosulphate with final concentration 2\% (Girard etal.,1977).

2- Using Ascorbic Acid and Copper Sulphat:

Stock solutions of $0.5 \mathrm{M}$ of ascorbic acid and $0.01 \mathrm{M}$ of copper sulphate were prepared in sterile distilled water and sterilized by Millipore filtration. The stock solutions were added to both viruses to obtain final concentration of $5 \mu \mathrm{g} / \mathrm{ml}$ of copper sulphate and $0.5,1.0$ and $1.5 \mathrm{mg} / \mathrm{ml}$ ascorbic acid.

The treated viruses were incubated at $37^{\circ} \mathrm{C}$ with continuous stirring (Madhusudana et al., 2004, Gabriel et al., 2004)

Complete viruses inactivation was confirmed by virus titration in cell culture as $1 \mathrm{ml}$ of treated viruses was collected at predetermined time interval. Virus samples were 10 fold serially diluted $10^{1}-10^{8}$ in maintenance media (MEM). The Prepared dilutions were dispensed onto MDBK pre cultured cell line in 96 well plates. Infected cultured plates were incubated in $\mathrm{CO}_{2}$ incubator and daily examined for detection of specific Cytopathic Effect (CPE).

\section{Sterility test:}

It was performed in accordance with USA Code of Federal Regulation, CFR (1987).

\section{Safety test:}

It was performed in accordance with USA Code of Federal Regulation, CFR (1987).

1- Mice:10young mature mice each weighting 10-15gm.

2- Rabbit (As a model for cattle): 6young mature rabbit.

\section{RESULT AND DISCUSSION}

Bovine Respiratory Diseases (BRD) have crucial and serious impact on the beef and dairy cattle industry, both for stocker and feedlot entities. Economic losses result from death, decreased performance of diseased cattle. Pneumo enteritis problem in cattle and calves in Egypt is caused by viral agents include Bovine Viral Diarrhea Virus (BVDV), Infectious Bovine Rhinotracheitis Virus (IBRV), Parainfluenza-3 Virus (PI-3V) and Bovine Respiratory Syncytial Virus (BRSV) (Samira et al., 2001). Optimization of the conventionally produced vaccine is absolutely necessary especially in terms of the inactivating material so as to modulate production recipe of superior quality vaccine. BEI has been used satisfactorily but its use in mass production loads put the producer at a risk because it is carcinogenic material ,also effort for getting rid of precipitating salt which lead to losing cell associated antigen as concluded by (Nietert, et al. 1974). 
there is a need to find an alternative inactivating agent which is not expensive and always available as ascorbic acid which is undergoing auto oxidation results in the formation of $\mathrm{OH}$ groups that could induce the virus inactivation (Murata et al., 1986).

The use of ascorbic acid (vitamin C) as an antiviral agent has been reported primarily as a prophylactic and therapeutic agent. During investigations of various chemical agents as preservatives and inactivators of viral diagnostic antigens، reference was found to the use of ascorbic acid as an antiviral product. Turner (1964) reported the inactivation of vaccinia virus by ascorbic acid undergoing auto-oxidation catalyzed by copper. Similar reactions with bacterial, fungal and viral agents were described by Ericsson and Ludbeck (1955). While examining the survival of enteroviruses in food، Salo and Cliver (1978) also investigated the effect of ascorbic acid on polio-, coxsackie-, and echoviruses inactivation.

Our approach was to determine the effect of ascorbic acid on IBR and BVD viruses, as measured by the infectivity in cell cultures.

Concerning the preparation of stock virus for vaccin production, the present work optimized some conditions for yielding a high virus titer to be suitable for preparation of a potent inactivated viral antigen. The result revealed that propagation of BVDV and IBRV viruses in MDBK cells culture which was being carried out at 24 hours post seeding of the cells where the cells did not reach a complete confluence resulted in characterized by cytopathic effect represented by Granulation of cytoplasm, bunches of grapes formation in case of IBRV with infectivity titer $10^{7.5} \mathrm{TCID}_{50} / \mathrm{ml}$ and cell rounding, Shrinkage of the cell wall, Granulation of the cytoplasm,Vaculation, Cell elongation in case of BVDV with infectivity titer infectivity titer $10^{5.5} \mathrm{TCID}_{50} / \mathrm{ml}$ as shown in Table (1).

The experimental results comparing the effectiveness of BEI and different concentration of ascorbic acid and Cu2+ on BVD and IBR viruses represented in (table $2-3$ ) revealed that $0.001 \mathrm{M}$ of BEI made Complete inactivated IBR and BVD viruses occurred after $6 \& 4$ hours post treatment respectively after cyclization of 2bromoethylamine hydro bromide in alkaline solution (sodium hydroxide) (El-Sabbagh et al., 2001), while complete inactivated with different ascorbic acid solution (1.0 And $1.5 \mathrm{mg}$ of ascorbic acid $/ \mathrm{ml} \& 5 \mu / \mathrm{ml}$ of copper sulphate ) occurred at (more than 24 hours post tretement (h.p.t), 24 h.p.t) for IBR and (24,18 h.p.t.)for BVD viruses respectively at $37^{\circ} \mathrm{C}$ while $0.5 \mathrm{mg} / \mathrm{ml} \& 5 \mu / \mathrm{ml}$ induced complete inactivation in both viruses at $48 \mathrm{hpt}$ and more than $24 \mathrm{~h}$.p.t respectively at $37^{\circ} \mathrm{C}$, these findings are coincidence with those obtain by (White et al., 1986) Who emphasized that the autooxidation of ascorbic acid catalyzed with cupric ions liberate $(\mathrm{OH})$ group that inactivated vaccinia virus as well as inactivated HIV7 and bacteriophages(Murata et al., 1986). 
The results clarified that the different inactivated viruses had no cytopathic effect on inoculated in MDBK cell culture and also the different inactivated viruses had no adverse effect on inoculated mice and rabbit (as a model of cattle) that was improved safety of virus. The potency of antigen measured through current study should be completed with further immunization with the two types of vaccines incorporated with either ascorbic acid or BEI and monitoring the cellular and humeral immunity.

Table 1. Cytopathic effect of IBR and BVD viruses on MDBK cells previously seeded within 24hrs:

\begin{tabular}{|c|c|c|c|}
\hline \multirow{2}{*}{ Viruses } & \multicolumn{2}{|r|}{ CPE } & \multirow[b]{2}{*}{ Virus Titer } \\
\hline & h.p.i & Signs & \\
\hline BVD virus & 72 & $\begin{array}{ll}\text { - } & \text { Granulation of the cytoplasm } \\
\text { - } & \text { Vaculation } \\
\text { - } & \text { Cell elongation }\end{array}$ & $10^{5.5} \mathrm{TCID}_{50} / \mathrm{ml}$ \\
\hline IBR virus & $24-36$ & $\begin{array}{l}\text { - } \quad \text { Cell rounding } \\
\text { - Shrinkage of the cell wall } \\
\text { - } \quad \text { Granulation of cytoplasm } \\
\text { - } \quad \text { Bunch grapes formation }\end{array}$ & $10^{7.5} \mathrm{TCID}_{50} / \mathrm{ml}$ \\
\hline
\end{tabular}
h.p.i:hour post inoculation.

Table 2. Inhibition of IBRV infection in MDBK cells after treatment with BEI and different concentration of ascorbic acid and $\mathrm{Cu}^{2+}$ at $37^{\circ} \mathrm{C}$ :

\begin{tabular}{|c|c|c|c|c|c|c|c|c|c|c|}
\hline \multirow{2}{*}{ Conc. of inactivator } & \multicolumn{10}{|c|}{ Virus infectivity titer $\left(\log _{10} \mathrm{TCID}_{50} / \mathrm{ml}\right)$ on HPI** } \\
\hline & $1 / 2$ & 1 & 2 & 4 & 6 & 8 & 12 & 16 & 18 & 24 \\
\hline $\mathrm{BEI}(0.001 \mathrm{Mol})$ & + & + & + & + & - & - & - & - & - & - \\
\hline $\begin{array}{l}\text { Ascorbicacid }(0.5 \mathrm{mg} / \\
\mathrm{ml})\end{array}$ & + & + & + & + & + & + & + & + & + & + \\
\hline $\begin{array}{l}\text { Ascorbic } \\
\text { acid }(1.0 \mathrm{mg} / \mathrm{ml})\end{array}$ & + & + & + & + & + & + & + & + & + & + \\
\hline $\begin{array}{l}\text { Ascorbic } \\
\text { acid }(1.5 \mathrm{mg} / \mathrm{ml})\end{array}$ & + & + & + & + & + & + & + & + & + & - \\
\hline
\end{tabular}

IBRV:Infectious Bovine Rhinotacheitis.HPI : hours post inoculation.

BEI: binary ethylenamine.

Table 3. Inhibition of BVDV infection in MDBK cells after treatment with BEI and different concentration of ascorbic acid and $\mathrm{Cu}^{2+}$ at $37^{\circ} \mathrm{C}$ :

\begin{tabular}{|l|c|c|c|c|c|c|c|c|c|c|}
\hline \multirow{2}{*}{ Conc. of inactivator } & \multicolumn{7}{|c|}{ Virus infectivity titer $\left(\log _{10} \mathrm{TCID}_{50} / \mathrm{ml}\right)$ on HPI } \\
\cline { 2 - 11 } & $1 / 2$ & 1 & 2 & 4 & 6 & 8 & 12 & 16 & 18 & 24 \\
\hline BEI(0.001Mol) & + & + & + & - & - & - & - & - & - & - \\
\hline $\begin{array}{l}\text { Ascorbic } \\
\text { acid(0.5mg/ml) }\end{array}$ & + & + & + & + & + & + & + & + & + & + \\
\hline $\begin{array}{l}\text { Ascorbic } \\
\text { acid(1mg/ml) }\end{array}$ & + & + & + & + & + & + & + & + & + & - \\
\hline $\begin{array}{l}\text { Ascorbic } \\
\text { acid(1.5mg/ml) }\end{array}$ & + & + & + & + & + & + & + & + & - & - \\
\hline
\end{tabular}

BVDV: Bovine Viral Diarrhea Virus. HPI: Hours Post Inoculation.

BEI: Binary Ethylenamine 
Table 4. Inactivation rate of IBRV \& BVDV by Different Concentration of Ascorbic Acid:

\begin{tabular}{|c|c|c|c|c|c|c|c|c|}
\hline \multirow{3}{*}{ Additive } & \multicolumn{8}{|c|}{ Virus Titers after Hrs. of Incubation at $37^{\circ} \mathrm{C}$} \\
\hline & \multicolumn{4}{|c|}{ IBR } & \multicolumn{4}{|c|}{ BVD } \\
\hline & 0 & 8 & 18 & 24 & 0 & 8 & 16 & 18 \\
\hline None Treated Virus & 7.5 & 7.5 & 6.5 & 6.3 & 6.5 & 5.5 & 5.5 & 5.4 \\
\hline Ascorbic $1 \mathrm{mg} / \mathrm{ml}+\mathrm{Cu}^{2+} 5 \mu \mathrm{g} / \mathrm{ml}$ & 7.5 & 5.3 & 2.0 & 0.7 & 6.5 & 2.8 & 0.5 & 0 \\
\hline Ascorbic $1.5 \mathrm{mg} / \mathrm{ml}+\mathrm{Cu}^{2+} 5 \mu \mathrm{g} / \mathrm{ml}$ & 7.5 & 4.8 & 1.2 & 0 & 6.5 & 1.5 & 0 & 0 \\
\hline
\end{tabular}

Table 5. Ascertainess of full inactivation of IBR and BVD viruses inactivated with different inactivators using laboratory animal as safety parameter:

\begin{tabular}{|l|l|l|l|}
\hline IBRV & h.p.t & Mice & Rabbit \\
\hline BEI $(0.001 \mathrm{Mol})$ & 6 & -ve & -ve \\
\hline ascorbic acid $(1 \mathrm{mg} / \mathrm{ml})$ & 24 & - -ve & -ve \\
\hline ascorbic acid $(1.5 \mathrm{mg} / \mathrm{ml})$ & 18 & - -ve & -ve \\
\hline BVDV & & & \\
\hline BEI $(0.001 \mathrm{Mol})$ & 4 & - ve & -ve \\
\hline ascorbic acid $(1 \mathrm{mg} / \mathrm{ml})$ & 18 & - ve & -ve \\
\hline ascorbic acid $(1.5 \mathrm{mg} / \mathrm{ml})$ & 16 & - -ve & -ve \\
\hline
\end{tabular}

IBRV:Infectious Bovine Rhinotachiitis virus.

BVDV:Bovine Viral Diarrhoea virus.

h.p.i: hour post treatment.

BEI: Binary Ethylenamine.

\section{CONCLUSION}

From the present obtained results, it could be concluded that ascorbic acid has a potential for being used as safe inactivating agent without marked affection the antigencity of the BVDV and IBRV viruses. The recommended concentration is ascorbic acid $(1.5 \mathrm{mg} / \mathrm{ml})$ because it made compelet viral inactivation for two virus.

\section{REFERENCES}

1. Brian, W.J.; Mahy, D.; Marc, H.V. and Regenmortel, V. 2010. Desk Encyclopedia of Animal and Bacterial Virology. Academic Press | 2009-10-30 | ISBN: 0123751446 | Pages: 646.

2. El-Sabbagh, M. M.; El-Sawalhy, A. A.; Samira, Said and Ghaly, H.M. 2001. Evaluation of combined inactivated respiratory virus vaccine pneumo-4 in pregnant cow dams.J. Vet. Med. Res. vol. III, No. 2 : 1-10.

3. Ericsson, Y., and H. Lundbeck. 1955. Antimicrobial effect invitro of the ascorbic acid oxidation. I. Effect on bacteria, fungi, and viruses in pure cultures. Acta Pathol. Microbiol. Immunol. Scand. Sect. B 37:493-506.

4. Gabriel Betanzos-Cabrera, Francisco J. Ram'ırez, José L. Muñoz, BLanca L .and Barrón, Rogelio Maldonado 2004. Inactivation of HSV-2 by ascorbateu(II) and its protecting evaluation in CF-1 mice against encephalitis, Journal of Virological Methods $120,161-165$. 
5. Girard, H.C., Bayramoglu, O.I., Er, LN and Burghut. 1977. Inactivation of viruses by binary Ethylenimine. Bull. IntIpid 87 (3-4):201-207.

6. Madhusudana, S. N., R. Shamsundar and S. Seetharaman. 2004. In vitro inactivation of the rabies virus by ascorbic acid. Int. J. Inf. Dis. 8: 211-25.

7. Murata, A., Kawaaki, M., Motomatsu, H., and Kato, F. 1986. Virus inactivating effect of D-iso ascorbic acid. J NutrSci Vitaminol;32(6):559—67.

8. Nietert, W.; Kellicut, L. and Kubinski, H. 1974. DNA complexes produced by acarcinogenic B-propiolactone Cancer Res., 34: 859-861.

9. Reed, L.T., and Muench, H. A. 1938. Simple method of calculating fiftypercent end point. Am J Hyg ;27:493-8.

10. Rawal, B.D., Bartolini F., Vyas G.N. 1995. In vitro inactivation of human immunodeficiency virus by ascorbic acid. Biologicals ;23(1):75-81

11. Ridpath, J. F. 2005. Practical significance of heterogeneity among BVDV strains: impact of biotype and genotype on U.S. control programs. Prev. Vet. Med. 15; 72(1-2):17-30.

12. Salo, R. J., and D. O. Cliver. 1978. Inactivation of enterovirusesby ascorbic acid and sodium bisulfite. Appl. Environ. Microbiol. 36:68-75.

13. Samira, S.T.; El-Sabbagh, M.M.A. and Ghaly, H.M. 2001. Preparation of combined inactivated BVD, IBR, PI3 and respiratory syncytial virus (BRSV). J. Egypt. Vet. Med. Ass. 61, no. 4: 251-263.

14. Turner, G.S. 1964. Inactivation of vaccinia virus by ascorbic acid J Gen Microbiol;35:75-80.

15. USA Code of Federal Regulation, CFR. 1987.

16. White, L.A., Freeman, C.Y., Forester, B.D., and Chappel, W.A. 1986. In vivo effect of ascorbic acid on infectivity of herpes viruses and paramyxoviruses. $J$ ClinMicrobiol;4(4):527-31.

17. WHO. 1996. WHO monograph "Laboratory8". Khodeir, M.H. 


\title{
فاعلية حمض الأسكوربيك كمادة مثبطة لفيروس التهاب القصبة

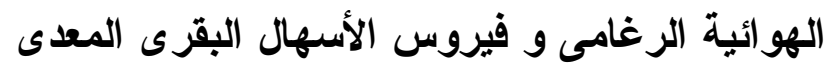

\author{
مها رأفت عبد الفضيل ، رشا ابراهيم الهوارى ، عفت لطفي السيد \\ معرة بحوث الأمصال و اللقاحات البيطرية العباسية - القاهرة.
}

في هذه الدراسة نناقش تأثير حمض الاسكوربيك (فيتامين ج) المحفز بسلفات النحاس كمثبط لفيروسي التهاب القصبة الهوائية الرغامى و فيروس الإسهال البقرى المعدي بالمقارنة

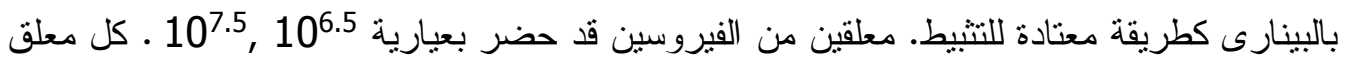
قد تمت معالجته علي حدا بكل من المادتين المثبطنين بتركيزات (5. ،1 و و 1.5 مليجرام/ملي)

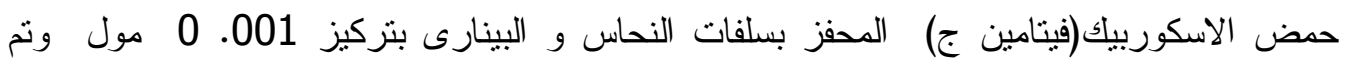

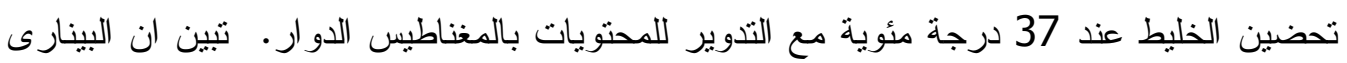

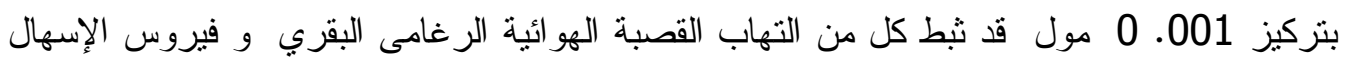

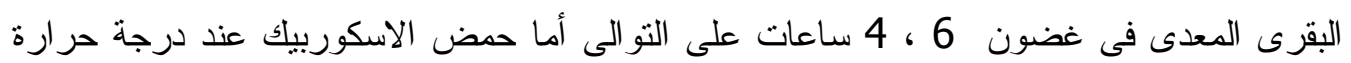

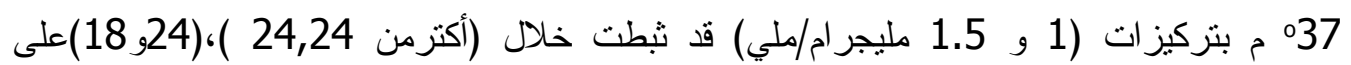

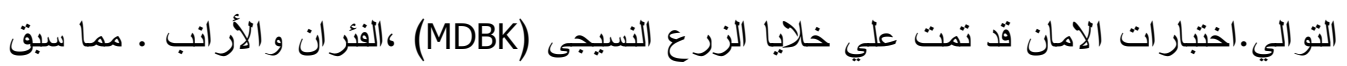
نستوضح أن حمض الاسكوربيك مادة مثبطة فعالة لكل من التهاب القصبة الهوائية الرغامى البقري

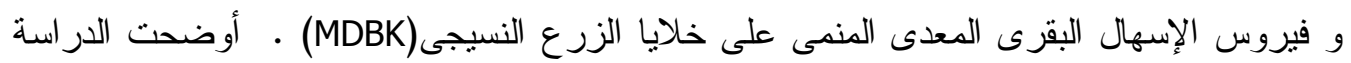

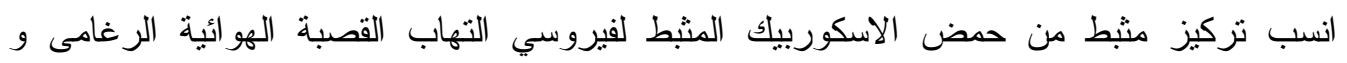
فيروس الأسهال البقرى المعدى هو (1.5 مليجر ام/ملي) لأنه ثبط كليتا كل من الفيروسين خلال 24

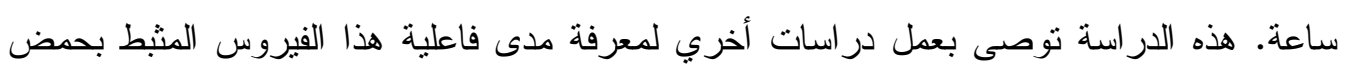
الاسكوربيك فى عمل اللقاح ومدى فاعلية حمض الاسكوربيك كمنشط مناعي موجود فى تركيبه خاصة عند استخدامه في صورته النانونية. 